\title{
Economic efficiency estimation of unmanned aircraft application for aerial photography
}

\author{
Artem Rada, Svetlana Kononova, Angela Yushkovskaya, and Aleksandr Kuznetsov \\ Kemerovo State University, 6, Krasnaya str., 650000 Kemerovo, Russia
}

\begin{abstract}
The use of unmanned aerial vehicles (hereinafter referred to as "UAV") is one of the most popular ways of collecting objective spatial data on the land plots under survey. The main advantages of UAVs include the significantly lower cost of surveying, design and complex cadastral works compared to traditional methods of determining coordinates (e.g. performing a tacheometric survey and plane-table survey). The designed sector of block No. 9 in the Yurga urban district of Kemerovo region with cadastral No. 42:36:0102001 (land category: residential), comprising 22 apartment buildings, is taken as an example. The economic performance of land plots marking, carried out with cadastral accuracy, based on data obtained using UAVs and without the use thereof, is assessed.
\end{abstract}

\section{Introduction}

According to electronic cadastral register, there are 1,128,884 land plots in the Kemerovo cadastral district, of which 494,204 , or $43.7 \%$, have boundaries that have been defined in accordance with the land legislation (Table 1) [1].

Table 1. Number of objects with defined boundaries in Kemerovo cadastral district

\begin{tabular}{|l|c|c|c|c|}
\hline \multicolumn{1}{|c|}{ Property } & $\begin{array}{c}\text { Kemerovo } \\
\text { cadastral } \\
\text { district }\end{array}$ & $\begin{array}{c}\text { with } \\
\text { boundaries, } \\
\mathbf{\%}\end{array}$ & $\begin{array}{c}\text { Yurga } \\
\text { cadastral } \\
\text { area }\end{array}$ & $\begin{array}{c}\text { with } \\
\text { boundaries, } \\
\text { \% }\end{array}$ \\
\hline Land plots & $1,128,884$ & 43.7 & 17,815 & 49.3 \\
\hline Buildings & 632,481 & 16.7 & 10,224 & 13.1 \\
\hline Facilities & 61,248 & 13.5 & 461 & 22.9 \\
\hline Assets under construction & 3,908 & 32.5 & 19 & 36.8 \\
\hline
\end{tabular}

According to the target model "Cadastral registration of land plots and items of immovable property" from the Order of the Government of the Russian Federation No. 147-r, dated 31.01.2017, by December 31, 2021 [2], the number of land plots with registered boundaries should reach $80 \%$, due to the fact that the main priority of state policy in the sphere of land and property relations is the rational and efficient use of land resources and real estate objects.

Kemerovo region lags far behind this indicator, as does the Yurga cadastral area, being part of it. For various reasons, properties may not have defined boundaries, but the low percentage of completeness of data regarding them raises the question of the amount of budget funds at various levels for financing complex cadastral works, as part of the 
subprogramme "Development of a unified system of state registration of rights and transactions in immovable property and state cadastral recording" and the state programme of the Kemerovo Region "Kuzbass asset complex for 2014-2022".

Land marking is one of the main elements of land management, which is a type of cadastral survey resulting in the measurement of a plot of land and indication of its coordinates at the terrain.

The cost of cadastral works depends on the designation purpose of the land plot, e.g. for individual housing construction, individual garage construction, personal subsidiary farming, horticulture and gardening there are separate limit tariffs set by the Government of a particular subject of the Russian Federation, but in our case we will give consideration to the cadastral works regarding the land plots on which apartment buildings are located.

The relevance and usefulness of complex cadastral works in relation to land plots on which apartment buildings are located can be attributed to a number of factors, both on the part of the apartment building owners and the municipal authorities. In the first case, the owners, having legalized their rights to the curtilage, have the right to dispose of the adjacent territory at their discretion, e.g. to erect transport, social infrastructure facilities, prevent unwanted development, participate in improvement programmes funded by municipal budgets, etc. In turn, in the development of a land survey project municipal authorities are guided by the goal of determining: boundaries of the existing and planned elements of the planning structure, frontage lines, building lines (setbacks from the frontage lines to determine the allowed location of buildings, structures and facilities), boundaries of the land plots being formed or altered, boundaries of public easement zones [3].

The object of this paper is to assess the cost-effectiveness and practical value of using UAV data in complex cadastral works to address the issues of completeness and accuracy of data in the Unified State Register of Real Estate.

\section{Materials and methods}

The paper is based on the economic analysis of the cost of complex cadastral works performed using aerial photography materials, generated with cadastral accuracy, as well as the use of other types of topographic survey on the territory of the projected sector of the block No. 9 in the Yurga urban district of Kemerovo region with cadastral No. 42:36:0102001.

The key approaches in the analysis are based on the methodology specified in the Schedule of Prices and Socially Necessary Labour Times (SNLT) for the production of design and survey products of land management, land cadastre and land monitoring, approved by the Order of the Committee on Land Resources and Land Survey of the Russian Federation dated December 28, 1995. [4], based on the expenditures of the organization collecting data on the land plot through the use of a UAV. The price ceiling for cadastral works, depending on the purpose, is determined according to the maximum ceiling price for land plot surveying established by the Government of a constituent entity of the Russian Federation.

\section{Results and discussion}

The owner of complex cadastral works, represented by the municipal authority, is responsible for supervising the process and accepting the results of the survey by the contractor. Contractor is selected through competitive bidding. In general, the preparation procedure for complex cadastral works includes the following stages [5]: drawing up an executive directive of the local authority as a basis for developing a land survey project; 
drawing up the textual and graphical part of the project; agreeing of the project with the competent authorities and holding a public hearing; approving the land survey project; concluding a contract for complex cadastral works.

In order to justify the purpose of the paper, we will calculate the cost of carrying out complex cadastral work. Table 2 and Figure 1 show the characteristic points of the boundary of the land plot to be surveyed [6]. Address of the land plot: Russian Federation, Kemerovo region - Kuzbass, Yurga urban district, Yurga, block No. 9. Land plot area 16.6 hectares (or 0.166 square kilometers, 166,000 sq.m.), the area is classified as natural difficulty category 1 for cadastral works. Number of apartment blocks is 22 with a theodolite traverse of 1 . Survey scale $-1: 500$

Table 2. Coordinates of characteristic points of the projected sector pf block № 9 in Yurga urban district

\begin{tabular}{|c|c|c|}
\hline \multirow{2}{*}{$\begin{array}{l}\text { Designation of characteristic } \\
\text { points of the boundary }\end{array}$} & \multicolumn{2}{|c|}{ Coordinates, $\mathbf{m}$} \\
\hline & $\mathbf{X}$ & $\mathbf{Y}$ \\
\hline 1 & 664564.96 & 1266613.50 \\
\hline 2 & 664309.57 & 1266885.50 \\
\hline 3 & 664000.32 & 1266595.21 \\
\hline 4 & 664029.10 & 1266564.35 \\
\hline 5 & 664042.68 & 1266565.30 \\
\hline 6 & 664261.37 & 1266330.73 \\
\hline
\end{tabular}

As an outcome, the owner of complex cadastral works, in this case Yurga city administration, should receive a draft territory layout in hard copy for further review and approval. This draft territory layout contains information on the land plot to be surveyed with and without the use of a UAV, i.e. using a geodetic method. The information obtained based on the survey often reveals large scale shifts in the boundaries of land plots, which require immediate correction of register errors.

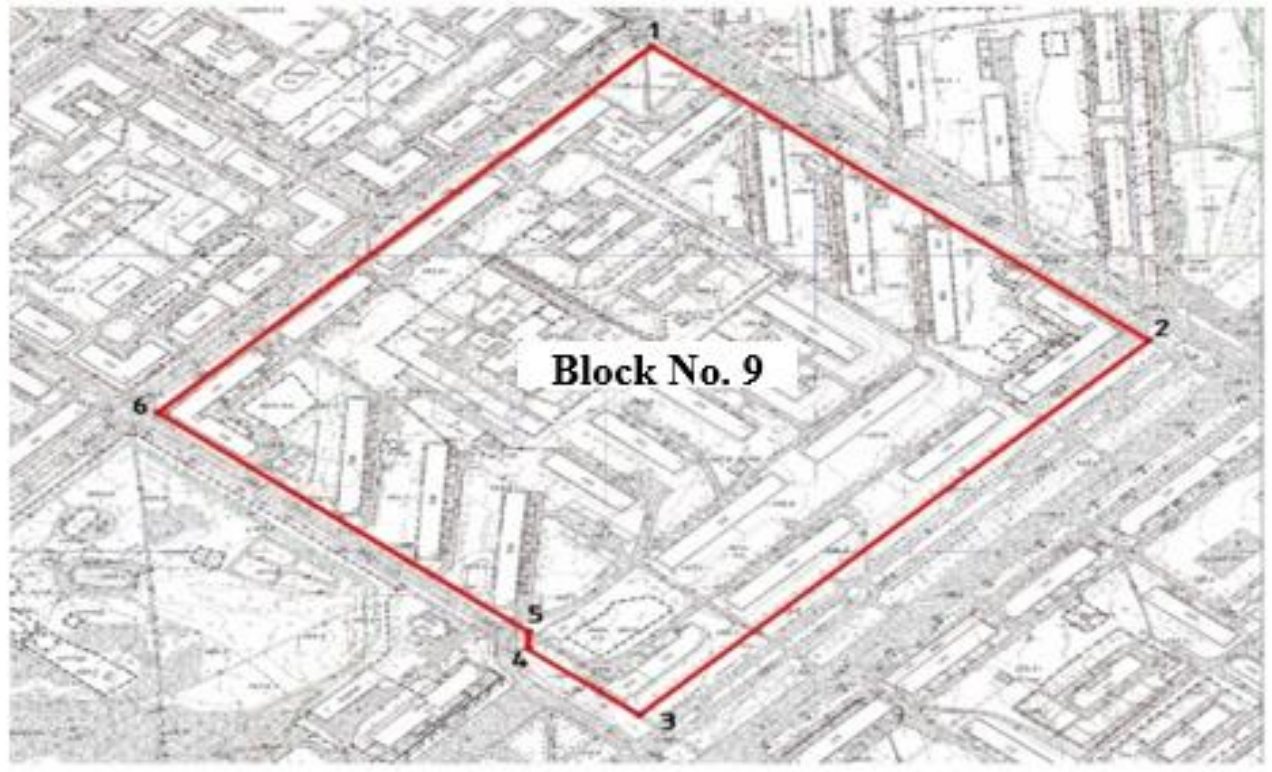

Fig. 1. Image of the land plot in respect of which complex cadastral work is being carried out

Table 3 presents an algorithm for calculating the total cost of complex cadastral work. 
Table 3. Steps for calculating the total cost of carrying out complex cadastral work

\begin{tabular}{|c|c|c|}
\hline Stages & Formulas & Calculation \\
\hline $\begin{array}{l}\text { 1. Determining the } \\
\text { cost of traversing }\end{array}$ & $\begin{array}{l}\mathrm{P} 1=\mathrm{a} 1 * \mathrm{k} 1+\mathrm{c} 1 * \mathrm{k} 2 \text {, where } \\
\mathrm{a} 1, \mathrm{c} 1-\mathrm{calculation} \text { price per } 1 \text { unit of } \\
\text { measurement according to the tables in the } \\
\text { Price Schedule; } \\
\mathrm{k} 1, \mathrm{k} 2 \text { - factors complicating the survey work. }\end{array}$ & $\begin{array}{l}\mathrm{P} 1=1230 * 0.44+199 * \\
1.24=787.96 \text { rubles }\end{array}$ \\
\hline $\begin{array}{l}\text { 1.1. Calculation of } \\
\text { the "c" coefficient, } \\
\text { as there are } 6 \\
\text { observation points } \\
\text { per } 1 \mathrm{~km}\end{array}$ & $\begin{array}{l}\mathrm{K} 1=1.0+0.08 *(\mathrm{n} 1-3), \text { where } \\
\mathrm{n} 1-\text { the number of observation points per } 1 \mathrm{~km} \\
\text { of traverse }\end{array}$ & $\begin{array}{l}\mathrm{K} 1=1.0+0.08 *(6-3) \\
=1.21\end{array}$ \\
\hline $\begin{array}{l}\text { 1.2. Calculation of } \\
\text { the "a" coefficient, } \\
\text { as the theodolite } \\
\text { traverse is less than } \\
15 \mathrm{~km} \text { long }\end{array}$ & $\begin{array}{l}\mathrm{K} 2=1.0-0.04(15-\mathrm{n} 2), \text { where } \\
\mathrm{n} 2-\text { traverse length }\end{array}$ & $\begin{array}{l}\mathrm{K} 2=1.0-0.04 *(15-1) \\
=0.44\end{array}$ \\
\hline $\begin{array}{l}\text { 2. Determining the } \\
\text { cost of a plane } \\
\text { surveying }\end{array}$ & $\begin{array}{l}\mathrm{P} 2=\mathrm{a} 2 * \mathrm{k} 3+\mathrm{c} 2 * \mathrm{k} 4 \text {, where } \\
\mathrm{a} 2-\text { calculation price per } 1 \text { unit of } \\
\text { measurement according to the tables in the } \\
\text { Price Schedule; } \\
\mathrm{k} 3, \mathrm{k} 4 \text { - factors complicating the survey work. }\end{array}$ & $\begin{array}{l}\mathrm{P} 2=1430 * 0.898+6 * \\
2.1=1,296.74 \text { rubles }\end{array}$ \\
\hline $\begin{array}{l}\text { 2.1. Calculation of } \\
\text { the decreasing } \\
\text { coefficient }\end{array}$ & $\begin{array}{l}\mathrm{K} 3=1.0-0.03 *(20-\mathrm{n} 3), \text { where } \\
\mathrm{n} 3-\text { area subject to surveying }\end{array}$ & $\begin{array}{l}\mathrm{K} 3=1.0-0.03 *(20- \\
16.6)=0.898\end{array}$ \\
\hline $\begin{array}{l}2.2 . \quad \text { Coefficient } \\
\text { (depending on the } \\
\text { survey scale) }\end{array}$ & $\mathrm{K} 4=2.1$, since the survey scale is $1: 500$ & 2.1 \\
\hline $\begin{array}{l}\text { 3. Total cost of } \\
\text { plane } \quad \text { survey } \\
\text { including } \mathrm{Kr}, \mathrm{Km} \\
\text { and VAT }(20 \%)\end{array}$ & $\begin{array}{l}\mathrm{P}=(\mathrm{P} 1+\mathrm{P} 2) * \mathrm{Kr} * \mathrm{Km}+(\mathrm{P} 1+\mathrm{P} 2) * \mathrm{Kr} * \\
\mathrm{Km} * 20 \% \text {, where } \\
\mathrm{Kr}-\text { is the regional coefficient (for Kemerovo } \\
\text { area } 1.3) ; \\
\mathrm{Km}-\text { multiplying factor }(14.2224379 \text { as of } \\
2020)\end{array}$ & $\begin{array}{l}\mathrm{P}=(787.96+1296.74) * \\
1.3 * 14.2224379+ \\
(787.96+1296.74) * 1.3 \\
* 14.2224379 * 0.2= \\
46253.24541 \text { rubles }\end{array}$ \\
\hline $\begin{array}{l}4 . \quad \text { Optimum } \\
\text { estimated cost } \\
\text { taking into account } \\
\text { Kdec }\end{array}$ & $\begin{array}{l}\text { Popt }=\mathrm{P} * \text { Kdec, where } \\
\text { Kdec }- \text { decreasing coefficient, as complex } \\
\text { cadastral work is carried out simultaneously on } \\
\text { all land plots }\end{array}$ & $\begin{array}{l}\text { Kdec }=46253.24541 * \\
0.7=32,377.27 \text { rubles }\end{array}$ \\
\hline $\begin{array}{l}\text { 5. Total cost of } \\
\text { complex cadastral } \\
\text { work }\end{array}$ & $\begin{array}{l}\operatorname{Pr}=\text { Popt } * \text { n } 4, \text { where } \\
\mathrm{n} 4-\text { number of land plots }\end{array}$ & $\begin{array}{l}\operatorname{Pr}=32,377.27 * 22= \\
712,299.94 \text { rubles }\end{array}$ \\
\hline
\end{tabular}

The total cost of complex cadastral works in the projected sector of Yurga urban district block No. 9 in respect of land plots where apartment buildings are located is 712,299.94 rubles.

There is a certain methodology for determining fees and fee limits depending on the man-hours involved in the performance of complex cadastral works. Based on the practice of cadastral surveying, it has been established that the most time-consuming stages in the work are preparatory and field work, which puts the geodetic method of surveying the territory at a disadvantage. The geodetic method is also more dependent on seasonal patterns, as the work is carried out in field conditions, which means that the duration of the field period varies in different territorial entities of the Russian Federation (in Kemerovo region it is 5 months). 
To calculate the cost of performance of complex cadastral works based on the materials of aerial survey carried out with cadastral accuracy, we will introduce parameters determined on the basis of labour requirement for carrying out the works (Table 4).

Table 4. Payroll calculation

\begin{tabular}{|c|c|c|c|c|c|}
\hline \multirow{2}{*}{ List of works } & \multicolumn{2}{|c|}{ Work performers } & \multirow{2}{*}{$\begin{array}{c}\text { Number of } \\
\text { hours on } \\
\text { the average }\end{array}$} & $\begin{array}{c}\text { Average } \\
\text { labour } \\
\text { remuneration } \\
\text { per day }\end{array}$ & $\begin{array}{c}\text { Labour } \\
\text { remuneration } \\
\text { (total) RUB }\end{array}$ \\
\hline $\begin{array}{c}\text { UAV aerial } \\
\text { photography } \\
\text { and creation of } \\
\text { orthophotomap }\end{array}$ & 2 & Purveyor & 3 & 3,000 & 6,000 \\
\cline { 2 - 6 } & 1 & Cartographer & 2 & 3,000 & 3,000 \\
\hline
\end{tabular}

Table 4 shows the main personnel involved in the complex cadastral work. The surveyor carries out fieldwork, i.e. his tasks include preparation of the equipment necessary for collecting data in the field, preparation of a field compilation survey and carrying out the aerial survey itself. The cartographer is part of the desktop team, collecting and analyzing the information that fills the finished orthophotomap later on.

Next, we calculate the organization's costs (Table 4). Depreciation of the UAV will be considered equal to 71,000 rubles (cost of the vehicle $-5,000,000$ rubles, number of flights according to documentation -70$)$.

Table 5. Estimate of organization's expenses

\begin{tabular}{|c|c|c|c|c|}
\hline Name of expenditures & Expenditure rate & \multicolumn{2}{|c|}{ Recovery } & Expenditures (RUB) \\
\hline Regional coefficient & 1.3 & \multicolumn{2}{|c|}{0.3} & 2,700 \\
\hline Taxes & $+30.2 \%$ & \multicolumn{2}{|c|}{0.302} & $3,533.4$ \\
\hline Overhead & $50 \%$ & \multicolumn{2}{|c|}{0.5} & $43,116.7$ \\
\hline Revenue rate & $+30 \%$ & \multicolumn{2}{|c|}{0.3} & $14,805.03$ \\
\hline \multicolumn{4}{|l|}{ Total, rubles } & $64,155.13$ \\
\hline \multicolumn{2}{|l|}{ VAT } & $20 \%$ & 0.2 & $12,831.03$ \\
\hline \multicolumn{2}{|l|}{ Estimated total (RUB) } & & & $76,986.16$ \\
\hline
\end{tabular}

When surveying a land plot with area within $1<\mathrm{S}<20$ square kilometres, the costs to the organization remain approximately at the same level under the condition of one flight/landing by the electric aircraft, but the cost of services can be announced to the client in proportion to the area of the land plot on which the survey is carried out. Consequently, the closer the land area is to 20 square kilometres, the more cost-effective it is to perform survey. When surveying a land plot with area larger than 20 square kilometres, the cost becomes a multiple of the number of take-offs/landings.

The profitability threshold or break-even point for the organization performing aerial photography will be 76,986.16 rubles, where the survey area is 1 sq.km (100 hectares). If the surveyed area of a land plot is less than 1 square kilometre, the nature of determining the cost of cadastral work becomes more subjective, contractual.

Since the area of the assessed land plot located in the territory of the projected sector of block No. 9, Yurga urban district is less than $1 \mathrm{sq}$. $\mathrm{km}$, the cost of complex cadastral works will be equal to the profitability threshold, which is 9.26 times less than the cost of complex cadastral works performed using geodetic method.

Based on the practice in the Republic of Buryatia, we can calculate the price ceiling for cadastral works in relation to land plots on which apartment buildings are located. The limit ceiling price in this case is 6 robles per square metre [7]. As a result, the marginal total cost will be:

Marg. tot. $\mathrm{P}=(166,000) * 6=996,000$ rubles. 
Thus, the total cost of land marking of land plots performed with cadastral accuracy based on UAV data may increase by a maximum of 12.93 times; when performing complex cadastral works by geodetic method, the marginal increase is only possible up to $28.74 \%$.

\section{Conclusions}

The above calculations are relevant not only for land plots on which apartment buildings are located, but also for individual housing/garage construction, etc. To determine the marginal cost of complex cadastral works, for example, for individual housing construction, the maximum tariff is also applied; for the Kemerovo region it is 2,602 rubles for one land plot plus 261 rubles for its description [9].

The Kemerovo region is in need of a complex cadastral survey. An increase in the number of land plots with established boundaries in accordance with the requirements of Russian legislation will make it possible to eliminate deficiencies in the accuracy of information about the property in the Unified State Register of Real Estate and will generally accelerate civil transactions with land plots. Registration of land plots and real estate contributes to the identification of lost tax benefits and has an impact on increasing the investment attractiveness of the region [8]. This need can most effectively be met through the use of UAVs. IN the course of cadastral works, the use of UAVs is driven both by the economic benefits to the customer and by the work completion times. Additional advantages of opting for a UAVs for cadastral surveys include high-resolution imagery obtained due to the low flight altitude, less time-consuming data collection process, and the consistency with the environmental safety concept.

\section{References}

1. Electronic cadastral register, https://e-cadastre.ru

2. RF Government Order dated 31.01.2017 No. 147-p

3. The Federal Law of 03.07.2016, No. 373-FZ

4. Order of the Committee on Land Resources and Land Survey of the Russian Federation, Legislation Bulletin, 70 (1995)

5. Federal Law No. 221-FZ dated 24.07.2007

6. Unified Information System in Procurement, https://zakupki.gov.ru

7. Law of the Republic of Buryatia dated October 7, 2009 No. 1039-IV

8. A. O. Rada, S. A. Kononova, A. D. Kuznetsov, A. Ya. Yushkovskaya, Fundamental Research, 1, 84 (2021) http://fundamental-research.ru

9. Resolution board of administration of the Kemerovo region dated December 25, 2007 No. 361 